\title{
遍歴電子メ夕磁性体 $\mathrm{La}\left(\mathrm{Fe}_{0.90} \mathrm{Si}_{0.10}\right)_{13}$ の 1 次磁気相転移の動的観察
}

\author{
東北大学大学院生 川本 直 幸 \\ 東北大学多元物質科学研究所 村上恭和進藤大輔深道和 明 \\ 東北大学大学院工学研究科 藤 枝俊 藤出麻哉
}
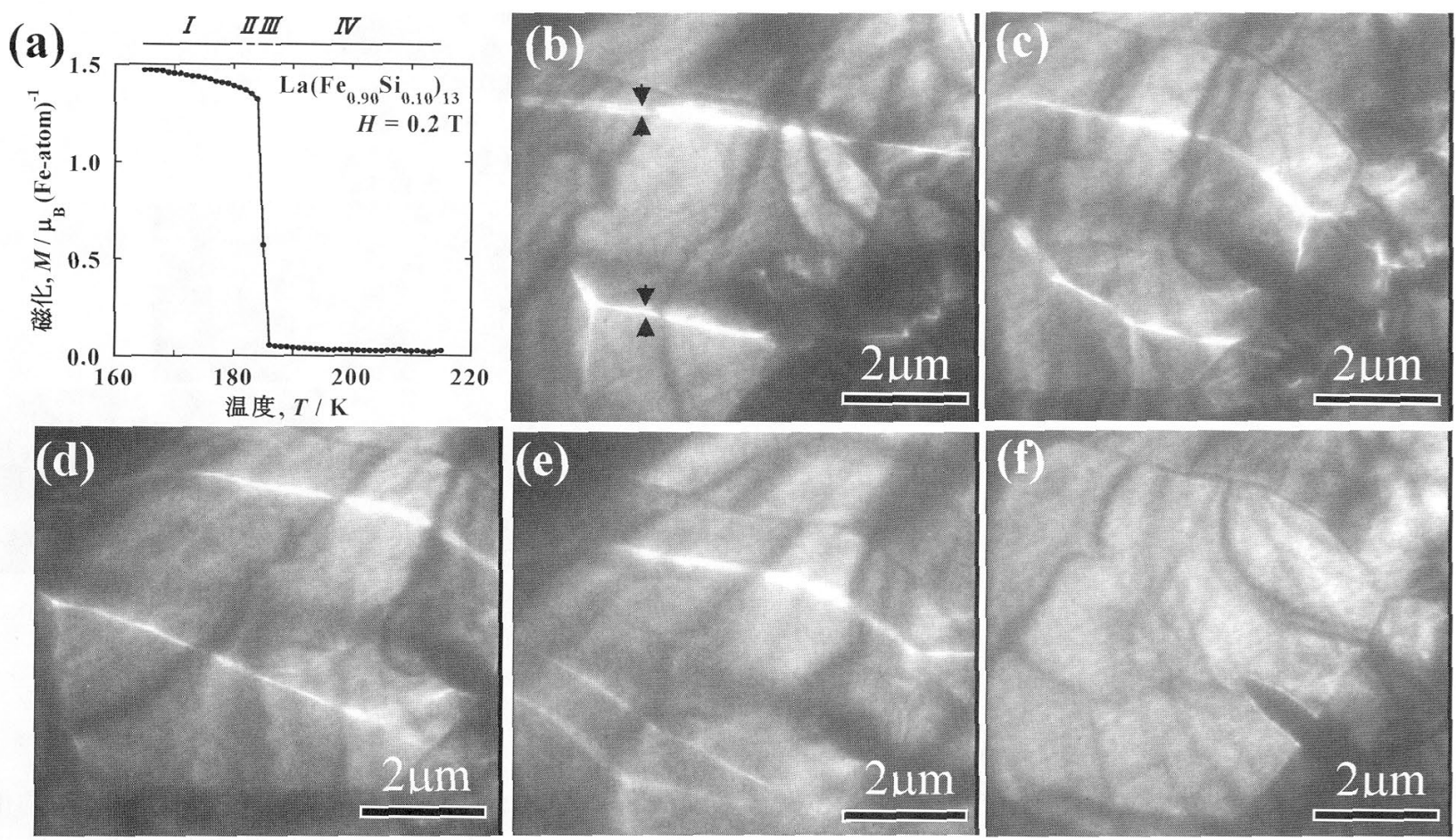

Fig. 1 (a) $\mathrm{La}\left(\mathrm{Fe}_{0.90} \mathrm{Si}_{0.10}\right)_{13}$ 化合物 (キュリー温度 $\left.T_{\mathrm{C}}=184 \mathrm{~K}\right)$ の $0.2 \mathrm{~T}$ の磁場下における熱磁化曲線, (b) -(f) 強磁 性一常磁性相転移の磁壁の移動抒よび消失過程を示すローレンツ顕微鏡像.

磁性体は一般的に温度誘起に伴う常磁性一強磁性 2 次相転移を示すが，遍歷電子メ夕磁性 $\mathrm{La}\left(\mathrm{Fe}_{x} \mathrm{Si}_{1-x}\right)_{13}$ 化合物は, キュリ一温度 $T_{\mathrm{C}}$ に抢いて常磁性一強磁性 1 次相転移を示す ${ }^{(1)}$. 本化合物访, 巨大な自発体積磁 歪打上び磁気熱量効果者示し, 近年, 磁気冷凍用材料 として注目されている。これまでにもローレンツ顕微 鏡法や電子線ホログラフィーを用いた磁気相転移の観 察が行われてきたが(2)，本化合物のような空間群の変 化を伴わない常磁性一強磁性 1 次相転移の観察は行わ れていない，そこで，本研究ではローレンツ顕微鏡法 を用い， $1.14 \mathrm{~K} / \min の$ 温度上昇過程に打いて $\mathrm{La}\left(\mathrm{Fe}_{0.90} \mathrm{Si}_{0.10}\right)_{13}$ 化合物が示す, 強磁性から常磁性へ の相転移挙動を動的に観察した. Fig. 1(a) は, 0.2 T の磁場中における本化合物の熱磁化曲線を示し, Fig. 1(b)加 (f)は, 温度上昇過程に抢㚈るローレンツ顕 微鏡像を示す。これらは, 磁気シールドを施した特殊 な対物レンズを用いて観察しており, 試料位置での磁 場は $0.2 \mathrm{mT}$ にまで低減されている. Fig. 1(a)の温度
範囲 Iでは, Fig. 1(b) に示す安定な磁区構造を形成 し, 矢先で示す磁壁の存在により, 試料が強磁性状態 であることが確認される。次に温度範囲IIで, Fig. $1($ b) $\rightarrow$ (c) で示される磁壁の移動が確認された。 その 後, $T_{\mathrm{C}}$ 近傍の温度範囲 $I I I$ に扔いて, Fig. $1(\mathrm{~d}) \rightarrow(\mathrm{e})$ $\rightarrow(f)$ の過程を巡る. ビデオレートの 1 コマに相当す る $1 / 30$ 秒の間に $(\mathrm{e}) \rightarrow(\mathrm{f})$ 問で磁壁が一瞬にして消失 し, 常磁性相に 1 次相転移する様子が直接観察され $た^{(3)}$.

\section{文献}

(1) A. Fujita, Y. Akamatsu and K. Fukamichi: J. Appl. Phys., $85(1999), 4756-4758$.

( 2 ) Y. Murakami and D. Shindo: Mater. Trans., 46(2005), 743755.

( 3 ) N. Kawamoto, Y. Murakami, D. Shindo, S. Fujieda, A. Fujita and K. Fukamichi: Mater. Trans., 46(2005), 1764-1767.

(2005年 8 月11日受理)

In Situ TEM Observation of First-order Magnetic Phase Transition in Itinerant-Electron Metamagnetic $\mathrm{La}\left(\mathrm{Fe}_{0.90} \mathrm{Si}_{0.10}\right)_{13}$ Compound; Naoyuki Kawamoto*, Yasukazu Murakami*, Daisuke Shindo*, Kazuaki Fukamichi*, Shun Fujieda**, Asaya Fujita** (*Institute of Multidisciplinary Research for Advanced Materials, Tohoku University, Sendai. ** Graduate School of Engineering, Tohoku University, Sendai) Keywords: itinerant-electron metamagnetic transition, Lorentz microscopy, first-order transition TEM specimen preparation: FIB (JEM-9310FIB) TEM utilized: JEM-3000F (300 kV) 